\title{
Hepatic gene expression in multiparous Holstein cows treated with bovine somatotropin and fed $n-3$ fatty acids in early lactation ${ }^{1}$
}

\author{
M. Carriquiry, ${ }^{2}$ W. J. Weber, S. C. Fahrenkrug, and B. A. Crooker ${ }^{3}$ \\ Department of Animal Science, University of Minnesota, St. Paul 55108-6118
}

\begin{abstract}
Multiparous cows were fed supplemental dietary fat and treated with bST to assess effects of n-3 fatty acid supply, bovine somatotropin (bST), and stage of lactation on hepatic gene expression. Cows were blocked by expected calving date and previous milk yield and assigned randomly to treatment. Supplemental dietary fat was provided from calving as either whole high-oil sunflower seeds (SS; $10 \%$ of dietary dry matter; $n-6 / n-3$ ratio of 4.6) as a source of linoleic acid or a mixture of Alifet-High Energy and Alifet-Repro (AF; 3.5 and 1.5\% of dietary dry matter, respectively; $\mathrm{n}-6 / \mathrm{n}-3$ ratio of 2.6 ) as a source of protected n-3 fatty acids. Cows were treated with 0 (SSN, AFN) or 500 (SSY, AFY) mg of bST every $10 \mathrm{~d}$ from 12 to $70 \mathrm{~d}$ in milk (DIM) and at 14-d intervals thereafter. Liver biopsies were collected on $-12,10,24$, and 136 DIM for gene expression analysis. Growth hormone receptor (GHR), insulin-like growth factor-I (IGF-I), IGF-binding protein-3 (IGFBP3), hepatic nuclear factor $4 \alpha(\mathrm{HNF} 4 \alpha)$, fibroblast growth factor-21 (FGF-21), and peroxisome proliferator-activated receptor $\alpha(P P A R \alpha)$ were the target genes and hypoxanthine phosphoribosyltransferase (HPRT) was used as an endogenous control gene. Expression was measured by quantitative real-time reverse transcription-PCR analyses of 4 samples from each of 32 cows (8 complete blocks). Amounts of hepatic HPRT mRNA were not affected by bST or diet but were increased by approximately $3.8 \%$ in early lactation $(3.42,3.52,3.54$, and $3.41 \times 10^{4}$ message copies for $-12,10,24$, and 136 DIM, respectively). This small change had little detectable impact on the ability of HPRT to serve as an internal control gene. Amounts of hepatic GHR, IGF-I,
\end{abstract}

\footnotetext{
Received September 1, 2008.

Accepted April 28, 2009.

${ }^{1}$ This work was supported in part by a Doctoral Dissertation Research Grant from the Graduate School at the University of Minnesota, a Hueg-Harrison Fellowship, and a Sigma Delta Epsilon Fellowship, all awarded to M. Carriquiry. Support for the study was also provided by the Agricultural Experiment Station at the University of Minnesota (project number 16-46).

${ }^{2}$ Current address: Facultad de Agronomia, Avda. Garzón 810, 12900 Montevideo, Uruguay.

${ }^{3}$ Corresponding author: crook001@umn.edu
}

and IGFBP3 mRNA were reduced by 1.5 to 2 -fold after calving. Expression of GHR and IGF-I increased and IGFBP3 tended to increase within $12 \mathrm{~d}$ (by 24 DIM) of bST administration. These effects of bST persisted through 136 DIM. Hepatic HNF4 $\alpha$ mRNA was not altered by DIM or any of the treatments. Abundance of PPAR $\alpha$ mRNA was unchanged through 24 DIM but increased by 136 DIM. There was a trend for an interaction of bST, diet, and DIM on PPAR $\alpha$ mRNA abundance from 24 to 136 DIM because the amount of PPAR $\alpha$ mRNA increased in SSN, SSY, and AFN cows but was not altered in AFY cows. The amount of FGF-21 mRNA increased markedly in early lactation but, like HNF4 $\alpha$ mRNA, was not affected by bST, diet, or their interactions. These results indicate 1) that bST induced increases in hepatic expression of GHR, IGF-I, and IGFBP3 when cows were in negative energy balance in early lactation, 2) there was no effect of reduced dietary n-6/n-3 content on hepatic gene expression, and 3 ) there was support for a potential homeorhetic role of hepatic FGF-21 via uncoupling the somatotropin-IGFaxis in early lactation.

Key words: somatotropin, n-3 fatty acid, hepatic gene expression

\section{INTRODUCTION}

The onset of lactation represents an impressive example of homeorhesis because an extensive array of physiological adaptations within multiple tissues occur in a coordinated manner to support the synthesis of large quantities of milk and preserve metabolic homeostasis simultaneously. The transition from pregnant and nonlactating to nonpregnant and lactating can increase nutritional requirements of the high-producing dairy cow by 4 -fold. However, these increased requirements are not accompanied by an immediate or sufficient increase in feed intake because feed intake usually decreases at the onset of parturition and the subsequent rate of increase is not as rapid as the increase in milk yield (Bell and Bauman, 1997). Because cows experience a period of significant negative energy balance in early lactation, they must mobilize body tissue to supply the energy and substrates needed to meet the metabolic demands 
for milk synthesis and peripheral needs (Bell and Bauman, 1997). Milk yield and reproductive performance are compromised if the magnitude and duration of this period of insufficient nutrient and energy supply are prolonged.

Efforts to minimize the duration of negative energy balance include the use of supplemental dietary fats. Feeding polyunsaturated fatty acids (PUFA) that can escape microbial biohydrogenation in the rumen provides a source of energy, and individual types of PUFA (n-6 vs. n-3, for example) can have differential effects on gene expression and metabolism (Clarke, 2004). Peroxisome proliferator-activated receptors (PPAR) are important factors in fatty acid regulation of gene transcription (activation and suppression), and a broad spectrum of fatty acids bind to and activate the primary subtype [proliferator-activated receptor $\alpha$ (PPAR $\alpha)$ ] of this transcription factor (Clarke, 2004). Hepatic nuclear factor $4 \alpha(\mathbf{H N F} 4 \boldsymbol{\alpha})$ is also involved in the regulation of transcription of several enzymes involved in gluconeogenesis and fatty acid metabolism and could be a target for fatty acid control of gene expression (Clarke, 2004). Alterations in the contribution of total PUFA and the ratio of n- 6 to $n-3$ fatty acids have been used in attempts to improve reproduction and immune function and to increase the functional food value of dairy products (Carriquiry et al., 2009a).

The liver plays a critical, central role in the coordinated effort to redirect nutrients toward milk synthesis. Somatotropin (ST, or growth hormone) is recognized as a major homeorhetic regulator (Bauman, 2000) and its direct effects are initiated by binding to and activation of the growth hormone receptor (GHR). One of the most significant direct effects is stimulation of IGF-I synthesis, which occurs predominantly in the liver (Sjögren et al., 1999). However, in contrast to the typical direct association between ST and IGF-I, circulating ST concentrations begin to increase shortly before parturition and IGF-I concentrations begin to decrease (Radcliff et al., 2003; Rhoads et al., 2004). Decreased expression of GHR, particularly the liverspecific GHR1A transcript, is one of the mechanisms involved in the periparturient decrease in circulating IGF-I (Radcliff et al., 2006) and contributes to results that indicate milk yield and IGF-I response to bST administration are greater in later lactation when cows are in positive energy and nutrient balance (Bauman, 2000). Hepatic fibroblast growth factor-21 (FGF-21) is an important regulator of lipid and carbohydrate metabolism (Kharitonenkov et al., 2007), and recent evidence indicates that during fasting, FGF-21 inhibits the signal transducer and activator of transcription 5 signaling pathway downstream of janus kinase 2 (Inagaki et al., 2008. Thus, homeorhetic properties of
FGF-21 could be expressed through uncoupling of the ST-IGF axis during the onset of lactation.

We hypothesized that changes in hepatic gene expression associated with the homeorhetic coordination of hepatic adaptation to the onset of lactation would be altered by differences in the dietary n- 6 to n-3 fatty acid ratio and by bST administration. Our objectives were to determine effects of initiation of bST administration in early lactation and consumption of dietary fat enriched with n-6 or n-3 fatty acids on hepatic gene expression in periparturient multiparous Holstein cows. We focused on genes associated with the ST-IGF axis and lipid and glucose metabolism.

\section{MATERIALS AND METHODS}

\section{Animals, Experimental Design, and Treatments}

Detailed descriptions of the diets, animal management, data and sample collection and analyses, and production responses have been reported elsewhere (Carriquiry et al., 2009a). Briefly, multiparous cows (n = 59) were fed a dry cow diet beginning 3 wk before their expected calving date. Cows were blocked by expected calving date and previous milk yield (305-d mature equivalent) and assigned randomly to 1 of 4 treatments in a $2 \times 2$ factorial arrangement of bST (0 or $500 \mathrm{mg} /$ injection) and source of supplemental dietary fat. Treatment diets contained either whole high-oil sunflower seeds (10\% of dietary DM; SS) as a source of linoleic acid (dietary n-6/n-3 ratio $=4.6$ ) or a mixture of Alifet-High Energy and Alifet-Repro (Alifet USA, Cincinnati, OH; 3.5 and $1.5 \%$ of dietary DM, respectively; $\mathbf{A F}$ ) as a source of $\mathrm{n}-3$ fatty acids (dietary $\mathrm{n}-6 / \mathrm{n}-3$ ratio $=2.6$ ). Alifet-High Energy is a microcrystallized rumen-inert energy concentrate made from animal fat (99\%) rich in SFA (57\% stearic acid; $25 \%$ palmitic acid). Alifet-Repro is a microcrystallized rumen-inert fat (flaxseed oil and fish oil) that is enriched with the n-3 fatty acids linolenic (C18:3, 15.7\%), eicosapentaenoic (C20:5, 1.3\%), and docosahexaenoic $(\mathrm{C} 22: 6,1.3 \%)$ acids. Dietary n-6/n-3 was calculated as the ratio of (18:2 cis- 9 , cis- 12$)$ to $(18: 3$ cis- 9 , cis- 12 , cis $15+\mathrm{C} 20: 5+\mathrm{C} 22: 6)$. The SS and AF diets contained 383 and $265 \mathrm{mg}$ of $18: 2$ cis-9, cis-12 per gram of total fatty acid, which would provide 756 and $463 \mathrm{~g}$ of 18:2 cis-9, cis-12 for cows that consumed $25 \mathrm{~kg}$ of $\mathrm{DM} / \mathrm{d}$, respectively (Carriquiry et al., 2009b).

Diets were fed as TMR and were formulated to meet nutritional needs (NRC, 2001) of the cows. Diets were composed primarily of alfalfa haylage, corn silage, highmoisture shelled corn, and soybean meal. The dry cow diet contained $17.7 \% \mathrm{CP}$ and $1.70 \mathrm{Mcal}$ of $\mathrm{NE}_{\mathrm{L}-\mathrm{Actual} \text { DMI }}$. Treatment diets were designed to differ only in the type of fatty acids they contained and were formulated to 
contain similar amounts of $\mathrm{NE}_{\mathrm{L}}(1.68$ and $1.71 \mathrm{Mcal} /$ $\mathrm{kg}$, respectively) at a predicted peak DMI of $29.9 \mathrm{~kg} / \mathrm{d}$ (4.7× maintenance; NRC, 2001). However, $\mathrm{NE}_{\mathrm{L}-\mathrm{Actual}}$ DMI throughout the study were 1.54 and $1.66 \mathrm{Mcal} / \mathrm{kg}$ for SS and AF, respectively. Dietary content of all other major components $(18.5 \% \mathrm{CP}, 18.5 \% \mathrm{ADF}$, and $28 \%$ $\mathrm{NDF}$ ) differed by less than $4 \%$ between treatment diets (Carriquiry et al., 2009a).

Treatment diets were offered from calving. Administration of bST (Posilac; Monsanto Animal Agricultural Group, St. Louis, MO) was initiated on $12 \pm 3$ DIM after collection of a liver biopsy sample on $10 \pm 2$ DIM. Treatment with bST continued at 10-d intervals through $70 \pm 3$ DIM and at 14-d intervals thereafter. Treatments from the $2 \times 2$ factorial arrangement of diet (SS, AF) with $0(\mathbf{N})$ or $500 \mathrm{mg}(\mathbf{Y})$ of bST per injection were designated SSN, SSY, AFN, and AFY, and there were $15,16,15$, and 13 cows per treatment, respectively.

Liver biopsies were obtained from all cows in the study, but tissue from a subset of 32 cows ( 8 complete blocks) was used to evaluate effects of treatments and stage of lactation on alterations in hepatic gene expression. Biopsies (approximately 1 to $1.5 \mathrm{~g}$ of tissue) were obtained at $-12 \pm 6,10 \pm 2,24 \pm 2$, and $136 \pm 2$ DIM with a 10-gauge custom biopsy instrument. After local intramuscular administration of $3 \mathrm{~mL}$ of $2 \%$ lidocaine $\mathrm{HCl}$, a 1-cm stab incision was made through the skin at the intersection of a line running from the tuber coxae to the shoulder joint with the 9th or 10th intercostal space. The biopsy instrument was inserted through the intercostal muscle into the liver, and a sample was collected. Liver samples were immediately placed in a tube with RNAlater (100 mg of tissue/mL; Ambion, Austin, TX) and stored for 7 to $21 \mathrm{~d}$ at $-20^{\circ} \mathrm{C}$. After removing RNAlater, tissue was stored at $-80^{\circ} \mathrm{C}$ until total RNA was isolated. Blood samples were collected at the time of biopsy and analyzed for IGF-I protein, glucose, and NEFA concentrations (Carriquiry et al., 2009a). There was no evidence of any effect of treatment on typical indices (mastitis, ketosis, milk fever, etc.) of cow health (Carriquiry et al., 2009a). Animal care and experimental procedures were approved by the University of Minnesota Institutional Animal Care and Use Committee.

\section{Isolation and Purification of RNA}

Total RNA was isolated using TRIzol (Invitrogen, Life Technologies, Carlsbad, CA), followed by precipitation with lithium chloride to remove inhibitors of cDNA synthesis and by DNase-treatment with a DNA-Free Kit (Ambion) to remove contaminating DNA. Concentration of RNA was determined by measuring absorbance at $260 \mathrm{~nm}$ (NanoDrop ND-1000 Spectrophotometer; Nanodrop Technnologies Inc., Wilmington, DE), and purity and integrity of all RNA isolates were assessed from $260 / 280$ and 260/230 absorbance ratios and profile analysis with an Agilent 2100 Bioanalyzer (Agilent Technologies, Palo Alto, CA). The RNA integrity number of each sample was $\geq 8$. Isolated RNA was stored at $-80^{\circ} \mathrm{C}$ until analyzed by quantitative real-time PCR.

\section{Quantitative Real-Time PCR}

Reverse transcription was conducted using the SuperScript III First-Strand Synthesis System Kit (Invitrogen) with random primers and $1 \mu \mathrm{g}$ of total RNA was added as a template. Primers (Table 1) were designed (Primer Express Software; Applied Biosystems, Foster City, CA) specifically to amplify cDNA for GHR, HNF4 $\alpha$, IGF-I, IGF-binding protein-3 (IGFBP3), FGF-21, and PPAR $\alpha$ as target genes of interest and for hypoxanthine phosphoribosyltransferase (HPRT) as an endogenous control. Before use, primer product size (1\% agarose gel separation) and sequence (capillary electrophoretic DNA analyzer ABI3130x1; Applied Biosystems) were determined to ensure that the primers produced the desired amplification products (results not reported). Polymerase chain reactions were performed in $1 \times$ SYBR Green universal master mix (SYBR GreenER qPCR SuperMix; Invitrogen), equal amounts $(300 \mathrm{n} M)$ of the forward and reverse primers (Integrated DNA Technologies, Coralville, IA), and 3 $\mu \mathrm{L}$ of diluted (1:7.5 in RNase/DNase free water) cDNA, for a final volume of $25 \mu \mathrm{L}$. Samples were analyzed in triplicate in a 96-well plate using an ABI Prism 7300 Sequence Detector (Applied Biosystems). Standard amplification conditions were $2 \mathrm{~min}$ at $50^{\circ} \mathrm{C}, 10 \mathrm{~min}$ at $95^{\circ} \mathrm{C}$, and 40 cycles of $15 \mathrm{~s}$ at $95^{\circ} \mathrm{C}$ and $60 \mathrm{~s}$ at $60^{\circ} \mathrm{C}$. Dissociation curves were generated after the last cycle. Each plate included duplicate wells of water (no template) and no reverse transcription controls for each set of primers and cDNA standard curves for the genes being analyzed in the plate. Plasmids that encoded the GHR, HNF4 $\alpha$, IGF-I, IGFBP3, FGF-21, PPAR $\alpha$, or HPRT genes were diluted in yeast cDNA to achieve a starting concentration of $10^{6}$ gene copies $/ \mu \mathrm{L}$ for subsequent serial dilutions $\left(\mathrm{n}=7\right.$ dilutions from $10^{6}$ to $10^{0}$ ). Linear regression was used to estimate the number of copies of target and control gene message in the samples. Expression of each target gene was normalized to expression of the HPRT control gene.

\section{Calculations and Statistical Analysis}

Data were analyzed as a randomized block design by repeated measures using mixed model procedures (SAS 
Table 1. Primers used for the quantification of target and endogenous control gene cDNA

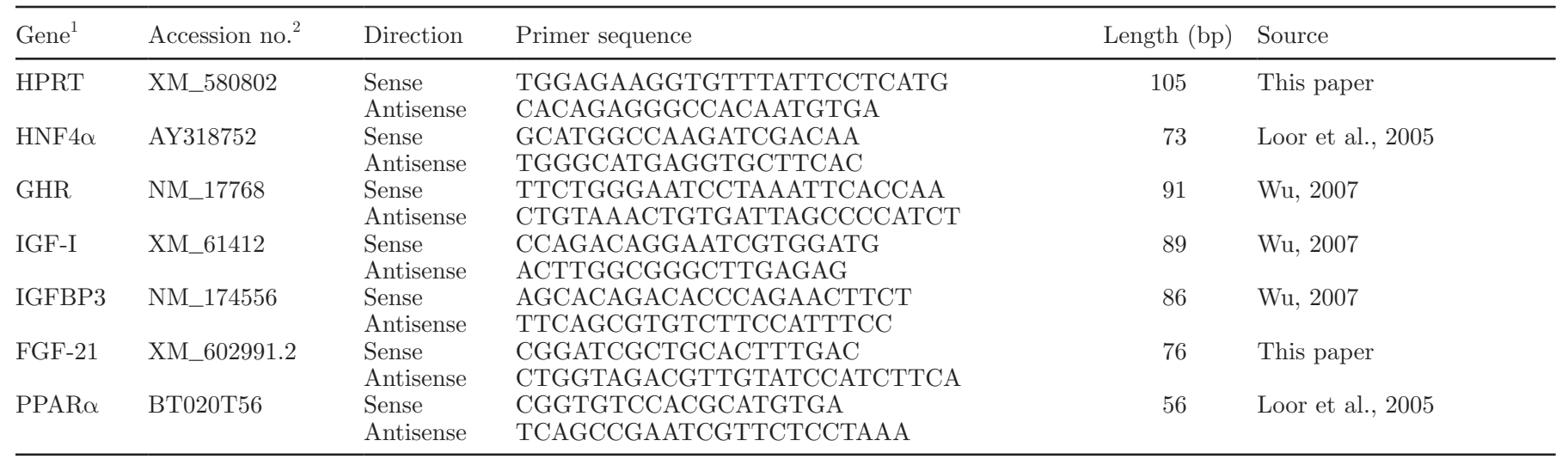

${ }^{1} \mathrm{HPRT}=$ hypoxanthine phosphoribosyltransferase (endogenous control gene); HNF4 $\alpha=$ hepatic nuclear factor $4 \alpha$; GHR $=$ growth hormone receptor; IGFBP3 = IGF-binding protein-3; FGF-21 = fibroblast growth factor-21; PPAR $\alpha=$ peroxisome proliferator-activated receptor $\alpha$.

${ }^{2}$ GeneBank sequences.

Institute Inc., Cary, NC) with DIM as the repeated effect, the spatial power law specified as the covariance structure, and block and reverse transcription assay (96well plate) as random effects. The study was designed to be analyzed with the prepartum expression value for each measurement per cow used as a covariate to assess effects of bST, diet, DIM, and their interactions. However, differences between expected and actual date of calving contributed to variation in when $(-31$ to -1 DIM) the prepartum samples were collected. This potential confounding was assessed by an identical analysis of the postpartum samples but without the covariate. Inclusion of results from samples collected at 10 DIM in analysis of the postpartum samples could confound assessment of the effects of bST because bST treatment was initiated after this biopsy. Therefore, effects of bST were assessed by an identical, noncovariate analysis of data from 24 and 136 DIM.

Results are reported as least squares means from the covariate analyses and were considered to differ when $P$ $<0.05$. Covariate means are reported with DIM profiles and impact of postpartum alterations assessed from a comparison of confidence intervals $(\alpha=0.05)$ between pre- and postpartum samples. Correlation and linear regression coefficients used to describe relationships between gene expression and plasma metabolites and hormones were estimated using procedures CORR and REG (SAS Institute Inc.).

\section{RESULTS}

Results from the covariate and the post hoc, noncovariate analysis of all postpartum data were consistent and data interpretation was unchanged for the effects of diet, DIM, and their interaction on abundance of mRNA for HPRT and all 6 target genes, except for an interaction of diet and DIM on amounts of IGFBP3
mRNA (described later in this section). This indicates that potential confounding by variation in actual date of calving had little impact on the results. However, the covariate analysis effectively reduced $(P<0.10)$ the impact of among-animal variation on hepatic expression of 5 of the 6 target genes $(P=0.17$ for FGF-21 expression), so results from the covariate analyses were used to describe overall effects of diet, DIM, and their interaction (Figures 1 and 2). Hepatic expression results

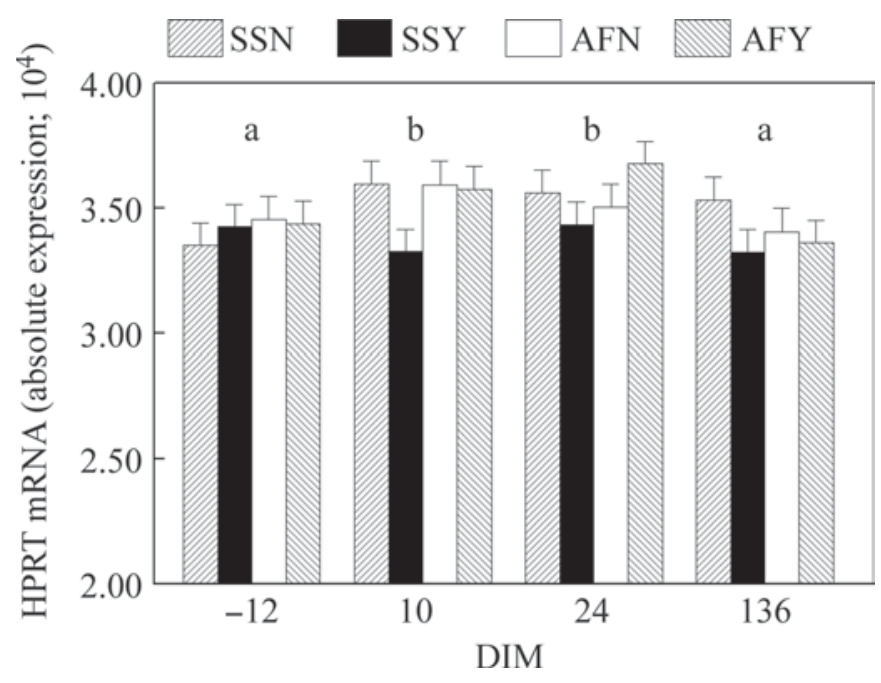

Figure 1. Effects of bST administration, source of dietary fat, and DIM on absolute hepatic expression of hypoxanthine phosphoribosyltransferase (HPRT) mRNA in multiparous Holstein cows. Cows were fed diets that contained whole high-oil sunflower seeds (SS, n-6/n-3 fatty acid ratio $=4.6$ ) or a mixture of Alifet-High Energy and AlifetRepro (Alifet USA, Cincinnati, $\mathrm{OH} ; \mathrm{AF}, \mathrm{n}-6 / \mathrm{n}-3$ fatty acid ratio = 2.6) from calving. Cows $(\mathrm{n}=32,8$ complete blocks) received 0 (SSN, AFN) or 500 (SSY, AFY) mg of bST every $10 \mathrm{~d}$ from 12 to 70 DIM and at 14-d intervals thereafter. ${ }^{\mathrm{a}, \mathrm{b}}$ Lowercase letters above the columns denote effects $(P=0.022)$ of DIM and indicate increased abundance in early lactation. There were no effects $(P>0.18)$ of bST, diet, their interaction, or their interactions with DIM on HPRT mRNA abundance. 

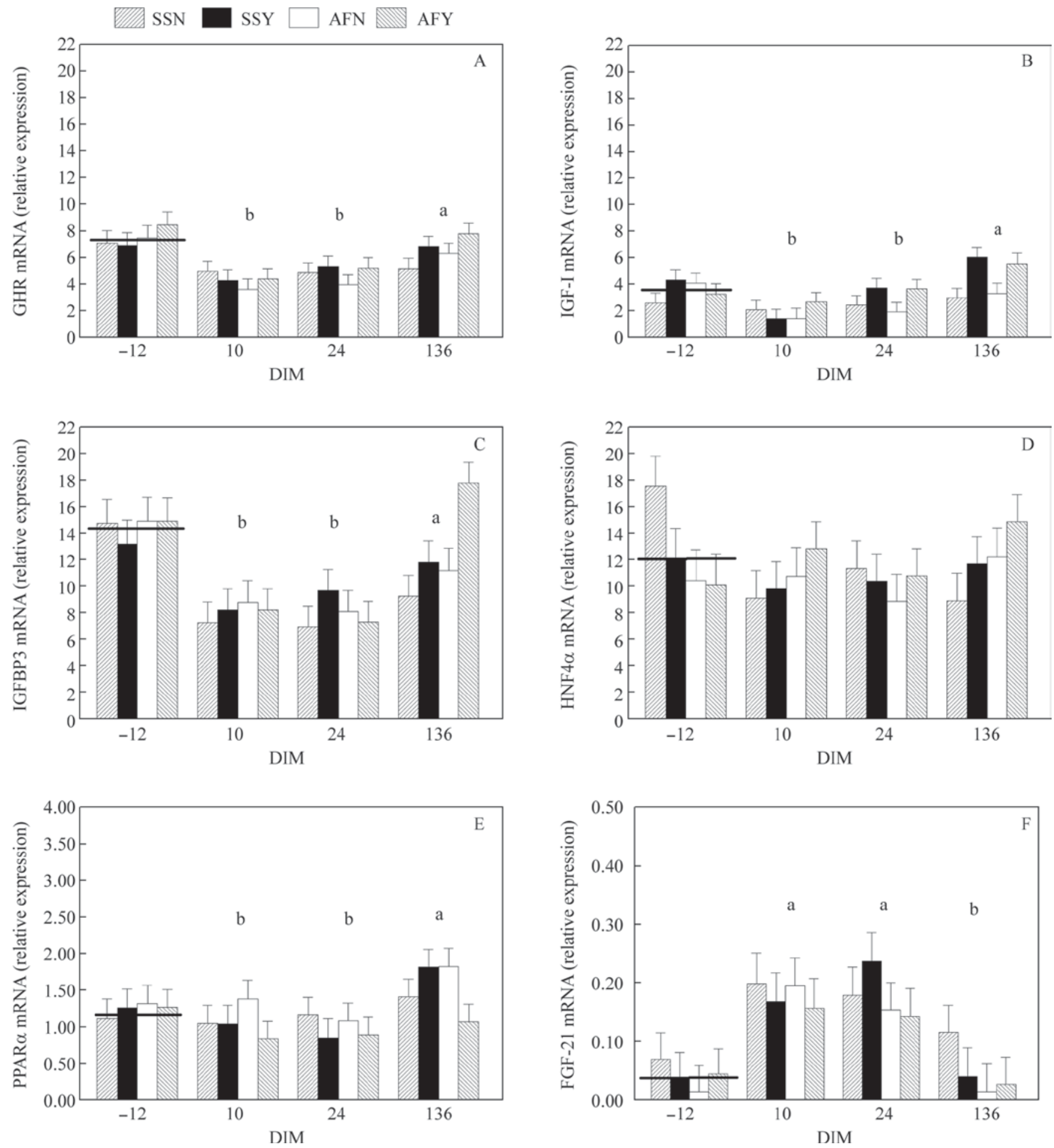

Figure 2. Effects of bST administration, source of dietary fat, and DIM on relative mRNA expression of growth hormone receptor (GHR; A), IGF-I (B), IGF-binding protein-3 (IGFBP3; C), hepatic nuclear factor $4 \alpha$ (HNF4 $\alpha$; D), peroxisome proliferator-activated receptor $\alpha$ (PPAR $\alpha$; E), and fibroblast growth factor-21 (FGF-21; F). Cows were fed diets that contained whole high-oil sunflower seeds (SS, n-6/n-3 fatty acid ratio $=4.6$ ) or a mixture of Alifet-High Energy and Alifet-Repro (Alifet USA, Cincinnati, OH; AF, n-6/n-3 fatty acid ratio = 2.6) from calving. Cows $(\mathrm{n}=32,8$ complete blocks) received 0 (SSN, AFN) or 500 (SSY, AFY) mg of bST every $10 \mathrm{~d}$ from 12 to 70 DIM and at 14-d intervals thereafter. The -12 DIM columns represent unadjusted treatment group means, with the mean covariate value represented by the horizontal black line. Error bars represent pooled standard error of the measurements. Postpartum values are covariately adjusted least squares means. ${ }^{a, b}$ Lowercase letters above the columns denote effects $(P<0.001)$ of DIM. Neither diet $(P>0.135)$ nor the interaction of diet and DIM $(P>0.199)$ affected mRNA abundance. Nonconfounded main effects of and interactions with bST are presented in Table 2. 
Table 2. Effect of dietary fat enriched with n-3 fatty acids, of bST, and of DIM on hepatic gene expression ${ }^{1}$ in multiparous Holstein cows at 24 and 136 DIM

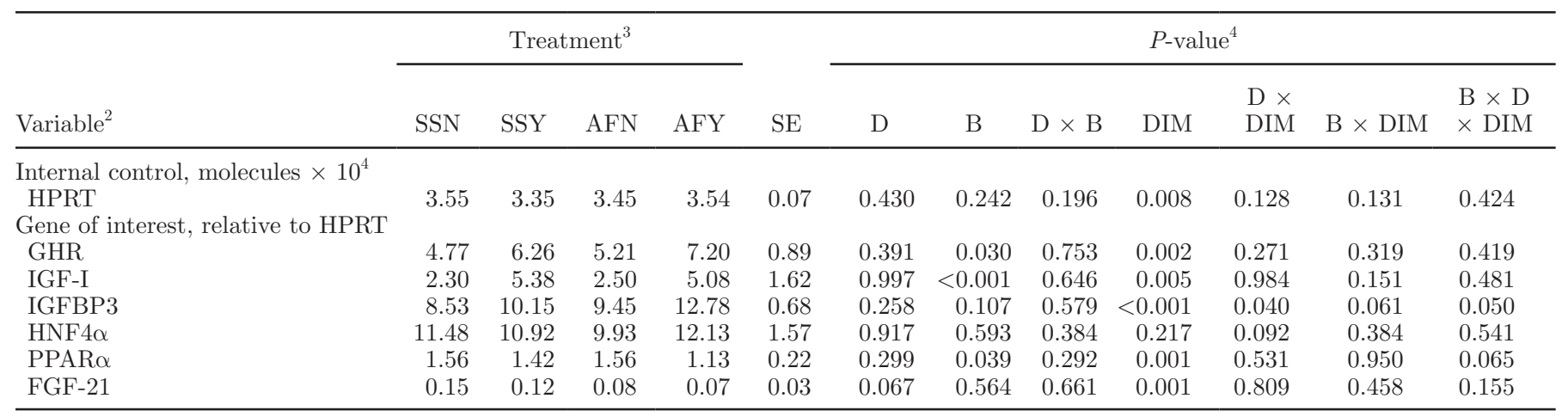

${ }^{1}$ Least squares means.

${ }^{2} \mathrm{HPRT}=$ hypoxanthine phosphoribosyltransferase; GHR = growth hormone receptor; IGFBP3 = IGF-binding protein-3; HNF4 $\alpha=$ hepatic nuclear factor $4 \alpha$; PPAR $\alpha=$ peroxisome proliferator-activated receptor $\alpha$; FGF-21 = fibroblast growth factor-21.

${ }^{3}$ Cows were fed diets that contained whole high-oil sunflower seeds (SS, n-6/n-3 fatty acids $=4.6$ ) or a mixture of Alifet-High Energy and AlifetRepro (Alifet USA, Cincinnati, OH; AF, n-6/n-3 fatty acids = 2.6) at least through 150 DIM. Treatments derived from a $2 \times 2$ combination of supplemental fat source (SS, AF) beginning at calving and 0 (SSN, AFN) or 500 (SSY, AFY) mg of bST administered every $10 \mathrm{~d}$ from 12 to 70 DIM and at 14-d intervals thereafter. Data are from a subset of 8 blocks ( $\mathrm{n}=32$ cows).

${ }^{4} \mathrm{D}=\operatorname{diet} ; \mathrm{B}=\mathrm{bST}$.

from the covariate and the nonconfounded (24 and 136 DIM only) analysis of the effects of bST were similar except for the effects of bST on GHR and IGFBP3 and the effects of interactions of bST with DIM on IGF-I, with diet on PPAR $\alpha$, and with diet and DIM on IGFBP3. These differences reflected the expected reduction in effects of bST attributable to inclusion of data before the initiation of bST treatment. Therefore, the nonconfounded analysis was used to describe effects of bST and its interactions with diet and DIM on hepatic mRNA abundance (Table 2).

The amount of hepatic HPRT mRNA increased $(P$ $=0.022)$ in early lactation (3.1 and $3.7 \%$ greater at 10 and 24 DIM relative to -12 DIM, respectively) and returned to prepartum values by 136 DIM (Figure 1). The decrease in HPRT mRNA from 24 to 136 DIM was also evident $(P=0.008)$ during the bST treatment interval (Table 2). There were no effects of bST, diet, their interaction, or their interactions with DIM on HPRT mRNA abundance in either analysis.

Amounts of GHR, IGF-I, and IGFBP3 mRNA decreased 1.5 - to 2-fold from -12 to 10 DIM, remained reduced at 24 DIM, and were greater $(P<0.001)$ at 136 than at 10 or 24 DIM (Figure 2, panels A, B, and C). Hepatic HNF $4 \alpha$ mRNA was the only target mRNA not affected $(P>0.55)$ by DIM (Figure 2D). Abundance of PPAR $\alpha$ mRNA was unchanged through 24 DIM but was 1.4 -fold greater $(P<0.001)$ at 136 than at 10 and 24 DIM (Figure 2E). Abundance of FGF-21 mRNA increased 4-fold after calving and was less $(P$ $<0.001$ ) at 136 than at 10 and 24 DIM (Figure $2 \mathrm{~F}$ ). There was no effect of diet and no interaction of diet and DIM $(P>0.199)$ on hepatic expression of any of the 6 genes analyzed.

Administration of bST increased abundance of mRNA for GHR $(P=0.030)$ and IGF-I $(P<0.001)$ and neither response was altered by duration of treatment $(P>0.151 ;$ Table 2$)$. The amount of IGF-I mRNA at -12 and 136 DIM was similar in cows not treated with bST but was 1.7 -fold greater $(P<0.05)$ at 136 DIM in cows treated with bST (Figure 2B). There was more IGFBP3 mRNA at 136 than at 24 DIM $(P<$ 0.001 ; Table 2) and this was influenced mostly by the large increase in IGFBP3 mRNA in AF cows treated with bST (Figure 2C). There was a trend $(P=0.107)$ for bST to increase IGFBP3 and a trend $(P=0.061)$ for expression of IGFBP3 to increase more rapidly in bST-treated cows (Table 2). There was no interaction of diet and bST $(P>0.47)$ on the amount of hepatic GHR, IGF-I, or IGFBP3 mRNA (Table 2). There was an interaction of diet, bST, and DIM $(P=0.05)$ on amounts of IGFBP3 mRNA during the bST treatment interval.

Administration of bST decreased $(P=0.039)$ the amount of PPAR $\alpha$ mRNA (1.56 vs. $1.28 \pm 0.22$; Table 2). There was no interaction $(P=0.292)$ of bST with diet but there was a trend $(P=0.065)$ for an interaction of diet, bST, and DIM on hepatic PPAR $\alpha$ mRNA abundance during the bST treatment interval. Amounts of HNF4 $\alpha$ mRNA were not affected $(P>$ 0.38 ) by diet, bST, DIM or their interactions, except for a trend $(P=0.092)$ for an interaction of diet and DIM (Table 2). However, this trend was not detected in the larger, more definitive covariate analysis of dietary 
effects (Figure 2D). Amounts of FGF-21 mRNA were not affected by diet, bST, their interaction, or their interactions with DIM, except for a trend $(P=0.067)$ for an effect of diet (Table 2). Again, this trend was not evident in the larger, more definitive covariate analysis of dietary effects (Figure 2F).

Amounts of GHR and IGF-I mRNA $(r=0.62 ; P$ $<0.001$; Figure 3A), GHR and IGFBP3 mRNA $(r$ $=0.58 ; P<0.001 ;$ Figure 3A) and IGF-I and IGFBP3 mRNA $(r=0.56 ; P<0.001$, not presented $)$ were highly correlated. Plasma IGF-I protein was correlated with the amount of hepatic mRNA for GHR $(r=0.43 ; P<0.001 ;$ Figure 3B), IGF-I $(r=0.27 ; P$ $=0.003 ;$ not presented $)$, and IGFBP3 $(r=0.37 ; P<$
0.001; not presented). Plasma glucose was correlated with the amount of hepatic mRNA for GHR $(r=$ $0.28 ; P<0.002$; not presented), IGF-I $(r=0.31 ; P$ $<0.001$; not presented $)$, and IGFBP3 $(r=0.41 ; P<$ 0.001 Figure 3C). Energy balance was correlated with the amount of hepatic mRNA for GHR $(r=0.38 ; P$ $<0.001$; Figure 3D), IGF-I $(r=0.26 ; P<0.006$; not presented), and IGFBP3 $(r=0.45 ; P<0.001$; not presented). The amount of FGF-21 mRNA was correlated negatively with energy balance $(r=-0.42 ; P$ $<0.001$; Figure 4A) and plasma glucose concentration $(r=-0.30 ; P=0.001$; Figure 4B) but was correlated positively with NEFA $(r=0.45 ; P=0.001$; Figure $4 \mathrm{C})$.
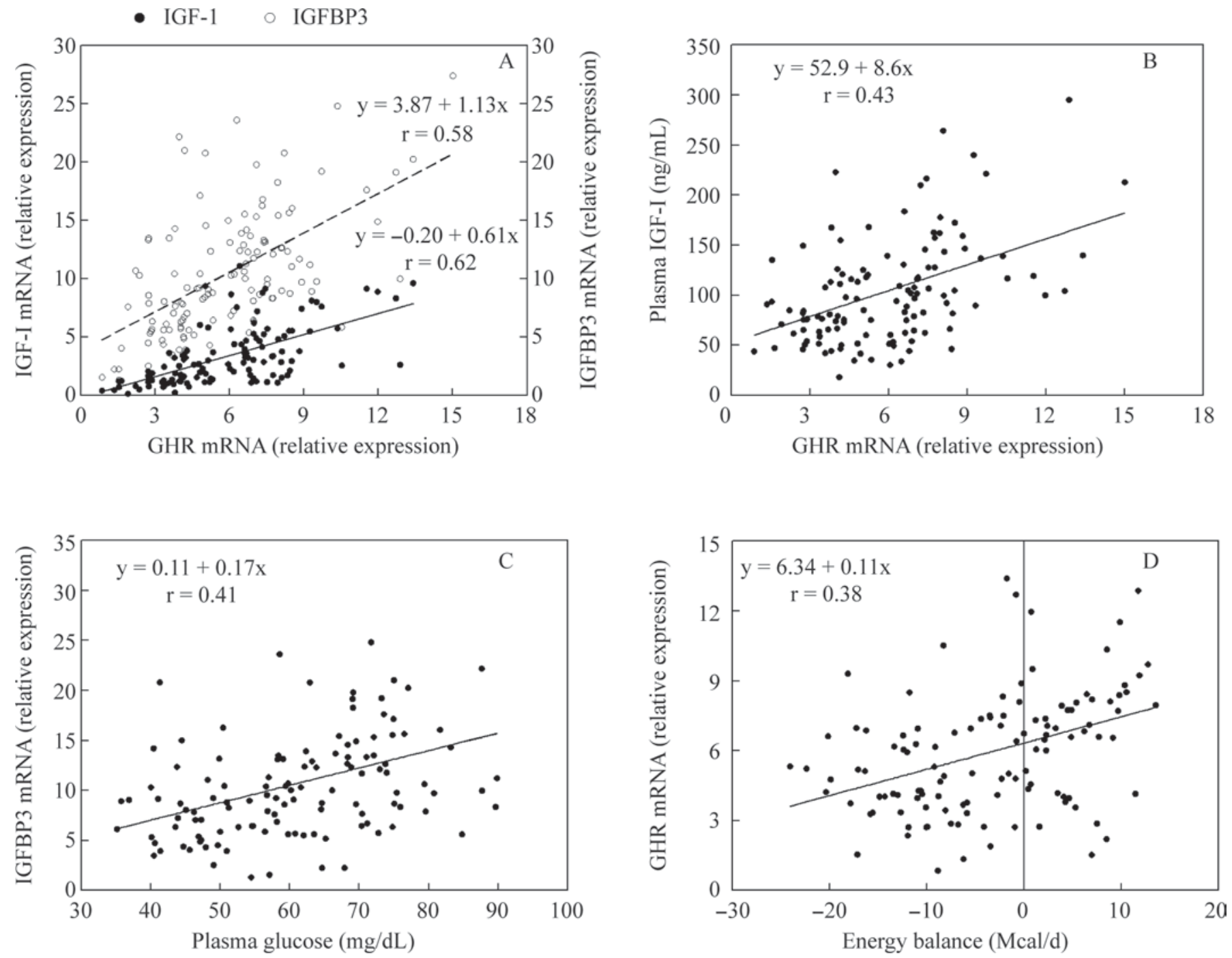

Figure 3. Relationship between hepatic mRNA for growth hormone receptor (GHR) and IGF-I (solid line and filled circles) or IGF-binding protein-3 (IGFBP3; dotted line and open circles; A), hepatic GHR mRNA and plasma IGF-I protein (B), plasma glucose and hepatic IGFBP3 mRNA (C), and energy balance and hepatic GHR mRNA (D) in multiparous Holstein cows ( $\mathrm{n}=32,8$ complete blocks) sampled at $-12 \pm 6$, $10 \pm 2,24 \pm 2$, and $136 \pm 2$ DIM. Cows were fed diets that contained whole high-oil sunflower seeds $(\mathrm{SS}, \mathrm{n}-6 / \mathrm{n}-3$ fatty acid ratio $=4.6)$ or a mixture of Alifet-High Energy and Alifet-Repro (Alifet USA, Cincinnati, OH; AF, n-6/n-3 fatty acid ratio = 2.6) from calving and received 0 (SSN, AFN) or 500 (SSY, AFY) mg of bST every $10 \mathrm{~d}$ from 12 to 70 DIM and at 14-d intervals thereafter. 


\section{DISCUSSION}

The genes examined in this study either have or are suspected to have important roles in the coordination of metabolic adaptation to physiological changes that occur with the onset of lactation, so changes in their hepatic expression profiles during the periparturient period would be expected. Somatotropin plays a dominant role in homeorhetic regulation (Bauman, 2000), and hepatic expression of the $1 \mathrm{~A}$ isoform of GHR and the presence of hepatic GHR1A protein are reduced during the periparturient period (Radcliff et al., 2003, 2006; Rhoads et al., 2004). Periparturient reductions in plasma IGF-I and IGFBP3 proteins are associated with this reduction in GHR1A (Radcliff et al., 2003). The promoter of the GHR gene that is responsible for synthesis of the GHR1A transcript in the liver of cattle contains a common cis-regulatory DNA element for HNF4a (Jiang and Lucy, 2001). Hepatic expression of $\mathrm{HNF} 4 \alpha$ during the periparturient period in dairy cows has been reported to increase (Loor et al., 2005) or remain constant (Wook Kim et al., 2004; Jiang et al., 2005). Hepatic HNF4 $\alpha$ is also involved in the regulation of transcription of several enzymes involved in gluconeogenesis and fatty acid metabolism and could be a target for fatty acid control of gene expression (Clarke, 2004).

Peroxisome proliferator-activated receptors are important factors in fatty acid regulation of gene transcription (activation and suppression) and a broad spectrum of fatty acids (i.e., linoleic acid, linolenic acid, highly unsaturated 20- and 22-carbon n- 6 or n-3 polyenoic fatty acids) bind to and activate the primary subtype (PPAR $\alpha$ ) of this transcription factor (Clarke, 2004). Fibroblast growth factor-21 is a novel member of the FGF family that is preferentially expressed in the liver (Nishimura et al., 2000), appears to have no mitogenic activity, but plays important endocrine roles in the regulation of lipid and glucose metabolism (Badman et al., 2007; Kharitonenkov et al., 2007; Inagaki et al., 2008). Our results demonstrate that hepatic expression profiles of all but HNF $4 \alpha$ change during the periparturient period and that relationships between and among these expression profiles can be altered by administration of bST, whereas no direct effects of source of dietary fat (altered n-6/n-3 fatty acid ratio) on these expression profiles were detected.

Accuracy of sample normalization can be increased by using more than one internal control gene, but efforts to identify a stably expressed internal control gene for a variety of experimental conditions continue (de Kok et al., 2005; Chen et al., 2006; Janovick-Guretzky et al., 2007a). Regardless, suitability of even presumably stable housekeeping genes should be validated,
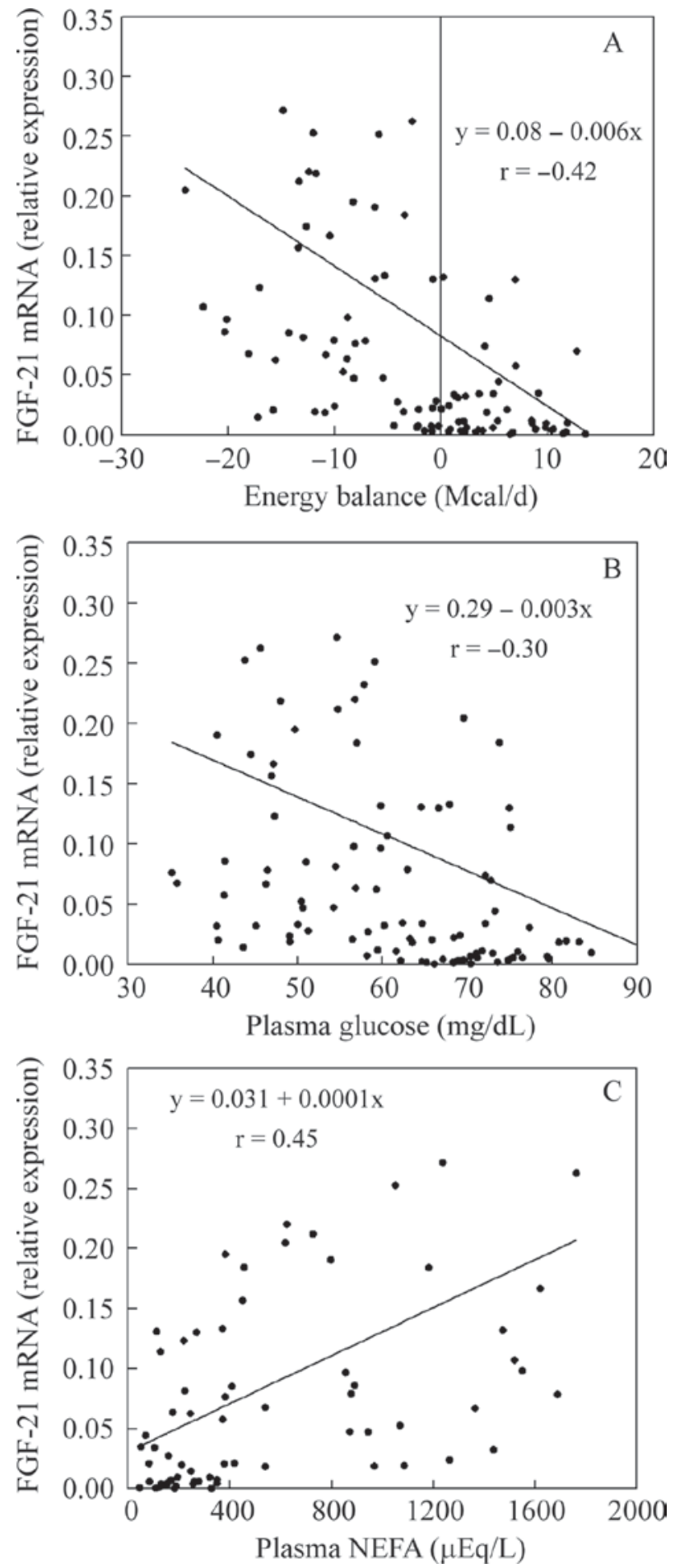

Figure 4. Relationship between hepatic fibroblast growth factor-21 (FGF-21) mRNA and energy balance (A), plasma glucose (B), and plasma NEFA (C) in multiparous Holstein cows $(\mathrm{n}=32,8$ complete blocks) sampled at $-12 \pm 6,10 \pm 2,24 \pm 2$, and $136 \pm 2$ DIM. Cows were fed diets that contained whole high-oil sunflower seeds (SS, n$6 / \mathrm{n}-3$ fatty acid ratio $=4.6$ ) or a mixture of Alifet-High Energy and Alifet-Repro (Alifet USA, Cincinnati, OH; AF, n-6/n-3 fatty acid ratio $=2.6$ ) from calving and received 0 (SSN, AFN) or 500 (SSY, AFY) mg of bST every $10 \mathrm{~d}$ from 12 to 70 DIM and at 14-d intervals thereafter. 
and software packages are available to help assess the suitability of genes as internal controls for a particular set of experimental conditions (Vandesompele et al., 2002; Andersen et al., 2004). The HPRT gene encodes an enzyme involved in recycling free purine bases by nucleotide conversion and has been identified as the single best of 13 frequently used endogenous control genes in tumor tissues (de Kok et al., 2005). Our evaluations of liver from growing dairy heifers (Wu, 2007) and periparturient dairy cows (Carriquiry et al., 2004) and those of Chen et al. (2006) from young and old rats support this observation. Although hepatic HPRT expression was increased slightly $(<4 \%)$ at 10 and 24 DIM in our current study, it was not affected by bST administration or by source of dietary fat and there was no effect of plate on HPRT expression within cow. Thus, this small change in HPRT expression apparently had little effect on the overall relative expression of our genes of interest. The reduction in HPRT expression from 24 to 136 DIM could inflate the effect of DIM on relative expression of our genes of interest during the bST treatment interval but should not alter effects of diet or bST. The potentially minimal impact of change in HPRT expression with DIM was confirmed by comparison with results obtained when HNF4 $\alpha$ was used as an internal control (results not presented). Hepatic gene expression of HNF4 $\alpha$ was not altered by DIM, bST, source of dietary fat, or their interactions in our study. When HNF4 $\alpha$ was used as an internal control, expression profiles and interpretation of results for genes (PPAR $\alpha$ and FGF-21) that were determined on the same 96-well plates as HNF4 $\alpha$ did not differ from those obtained when HPRT was used as the internal control. Although not definitive, these results indicate that the small increase in HPRT at 10 and 24 DIM should also have little effect on interpretation of our results. Nonetheless, this classical approach to identification of an appropriate internal control does not account for potential dilution effects that can occur when tissues are evaluated during periods of metabolic alteration (Vandesompele et al., 2002; Bionaz and Loor, 2007).

Somatotropin plays a critical role in the regulation of hepatic function and in homeorhetic coordination of nutrient use during early lactation in dairy cows (Bauman, 2000). Blood ST concentrations increase shortly after calving, but the typical direct association between ST and IGF-I is uncoupled when cows are in negative energy balance (Bauman, 2000). In our study, plasma IGF-I concentrations decreased during the periparturient period when energy balance decreased (Carriquiry et al., 2009a), and these changes were accompanied by parallel decreases in hepatic GHR and IGF-I mRNA. Administration of bST increased hepatic IGF-I mRNA but not plasma IGF-I protein to prepartum concentrations by 24 DIM when our cows were treated with bST. Wook Kim et al. (2004) have also reported earlier postpartum increases in IGF-I mRNA than IGF-I protein. The ternary complex of IGF-I, IGFBP3, and the acidlabile subunit is an important functional component of the somatotropic axis and is the major form of IGF-I in blood (Jones and Clemmons, 1995). Changes in hepatic IGFBP3 mRNA that mimic changes in blood IGFBP3 protein concentrations during lactation have been reported (Sharma et al., 1994). We demonstrated that hepatic IGFBP3 mRNA expression decreased in early lactation and that it tended to return to prepartum values earlier in cows treated with bST. Similar to our results, Loor et al. (2005) observed a gradual 3-fold decrease in hepatic IGFBP3 mRNA from -65 to 14 DIM. These profiles were similar to those of blood insulin concentrations and indicate that insulin-induced alterations in IGFBP3 could represent a mechanism by which insulin regulates plasma IGF-I concentrations. Hyperinsulinemic-euglycemic clamp studies with cows in early and mid lactation detected increased circulating IGF-I protein, and although blood IGFBP3 concentrations were not changed, the blood IGFBP3 to IGFBP2 ratio increased (Mashek et al., 2001). These and our results support the concept of a role for IGFBP3 in the molecular mechanisms that regulate the uncoupling of ST and IGF-I in dairy cows in early lactation. However, other IGFBP (i.e., IGFBP2) and the acid-labile subunit are also likely involved in this process.

Administration of bST to cows in positive energy and nutrient status (mid- to late lactation) increases circulating ST and IGF-I concentrations and increases milk yield by 10 to $20 \%$ through a chronic alteration of nutrient utilization (Bauman, 2000). When cows are in negative energy balance during early lactation, the ST-IGF axis is uncoupled and milk yield response to bST is reduced (Bauman, 2000). However, prolonged administration of bST to multiparous cows in early lactation can cause substantial increases in circulating IGF-I concentrations and in yields of milk and FCM before 70 DIM as well as during the entire (through at least 280 DIM) treatment period (Carriquiry et al., 2008, 2009a).

We demonstrated that initiation of bST treatment at 12 DIM, when cows were at their energy balance nadir, increased hepatic abundance of GHR and IGF-I mRNA within $12 \mathrm{~d}$ and that this effect persisted through at least 136 DIM. There was no effect of diet on hepatic GHR or IGF-I mRNA abundance; however, cows fed $\mathrm{AF}$ had greater concentrations of IGF-I protein (Carriquiry et al., 2009a), and cows fed $\mathrm{AF}$ and treated with bST had greater hepatic IGFBP3 mRNA expression as lactation progressed. Greater hepatic IGFPB3 mRNA 
could explain in part why plasma IGF-I concentrations returned to prepartum values between wk 8 and 12 of lactation in bST-treated cows, but not until after wk 24 of lactation in cows that were not treated with bST (Carriquiry et al., 2009a). This difference in plasma IGF-I between bST-treated and untreated cows occurred even though hepatic abundance of IGF-I mRNA in both treated and nontreated cows had returned to prepartum values by 136 DIM.

The GHR gene promoter responsible for synthesis of the hepatic GHR1A transcript in cattle contains a common cis-regulatory DNA element for transcription factor HNF4 $\alpha$ (Jiang and Lucy, 2001). Results from our study and others (Wook Kim et al., 2004; Jiang et al., 2005) have failed to demonstrate alterations in hepatic HNF $4 \alpha$ mRNA abundance or HNF $4 \alpha$ protein concentration in dairy or beef cows during the periparturient period or at later stages of lactation (56 or 140 DIM). In addition, administration of bST to our cows did not modify hepatic HNF4 $\alpha$ mRNA abundance in either an acute or a chronic manner. These results indicate that altered expression of $\mathrm{HNF} 4 \alpha$ is not responsible for alterations in abundance of hepatic GHR1A mRNA in dairy cows during the periparturient period or in response to bST or the source of dietary fat. However, effects of nuclear factors can occur through mechanisms other than altered expression. Odom et al. (2004) have demonstrated that $\mathrm{HNF} 4 \alpha$ plays a substantial role in the regulation of hepatic and pancreatic metabolism by binding directly to almost half of the actively transcribed genes.

Loor et al. (2005) sampled earlier in the dry period than we did, detected a periparturient decrease (from -65 to -14 DIM) in hepatic HNF4 $\alpha$ mRNA, and suggested that this decrease was associated with a general state of catabolism. In contrast to our results, these authors also detected a gradual increase in hepatic HNF $4 \alpha$ mRNA from -14 to 28 DIM and associated it with increased gluconeogenesis and fatty acid oxidation in early lactation. These contradictory results could be associated with differences in study design, analytical techniques, and cow characteristics. For example, the cows $(\mathrm{n}=5)$ used by Loor et al. (2005) reached energy balance nadir at 2 DIM and positive energy balance during wk 2 of lactation. Similarly, serum NEFA concentrations in their cows peaked at 5 DIM and returned to prepartum levels by 20 DIM (Loor et al., 2005). In contrast, our cows reached energy balance nadir at wk 2 of lactation and remained in negative energy balance during the first 10 to 15 wk of lactation. Plasma NEFA concentrations increased in our cows after calving, peaked at wk 4 of lactation, and returned to precalving concentrations by wk 8 of lactation (Carriquiry et al., 2009a).
The primary PPAR subtype expressed in the liver is PPAR $\alpha$, which is an important lipid sensor and plays a critical role in the regulation of cellular uptake, activation, and oxidation of fatty acids (Berger and Moller, 2002). Multiple fatty acids activate PPAR $\alpha$ and activation varies among tissue type and species (Khan and Vanden Heuvel, 2003). Our early-lactation diets provided more fat than is typically fed to dairy cows (about $8 \%$ of dietary DM) and were enriched with either n- 6 or n-3 PUFA, which have been identified as ligand activators of PPAR $\alpha$ (Clarke, 2004). In addition, our cows remained in negative energy balance and had increased plasma NEFA concentrations through 84 DIM. Although these conditions would be expected to increase hepatic PPAR $\alpha$ expression, we detected no alteration in hepatic PPAR $\alpha$ mRNA from -12 through 24 DIM. Our sampling schedule did not allow us to determine the pattern of PPAR $\alpha$ expression from 24 to 136 DIM, when PPAR $\alpha$ expression increased 1.7-fold compared with precalving values. In contrast, Loor et al. (2005) detected a 1.5-fold increase in hepatic PPAR $\alpha$ from -14 to 1 DIM that persisted (1.5- to 1.8-fold) through 49 DIM when dairy cows were fed to meet $100 \%$ of their prepartum energy requirement. Subsequent studies revealed that excessive prepartum caloric intake produced a hepatic inflammatory response and decreased pre- and postpartum hepatic expression of PPAR $\alpha$ and other genes involved in fatty acid oxidation (Loor et al., 2006; Janovick-Guretzky et al., 2007b; J. J. Loor, University of Illinois, personal communication). Similar to our results, Palin and Petit (2004) detected no effect of DIM on periparturient hepatic expression of PPAR $\alpha$ when cows consumed more than $100 \%$ of their energy requirement prepartum and were fed different sources of fat from -6 to 4 wk of lactation (M. F. Palin and H. V. Petit, Agriculture and Agri-Food Canada, personal communication).

Feeding trans 18:1 fatty acids to transition dairy cows has upregulated hepatic PPAR $\alpha$ mRNA content during the first month of lactation (Selberg et al., 2005), and feeding diets rich in n-3 PUFA to rats has increased hepatic PPAR $\alpha$ gene expression during the postprandial period (Levy et al., 2004). Cell culture (Zhou and Waxman, 1999) and rat (Olsson et al., 2003) studies indicate that bST counteracts the increase in peroxisomal $\beta$-oxidation induced by peroxisome proliferators (Yamada et al., 1995). Although our AF diet provided a source of trans 18:1 fatty acids and n-3 PUFA, hepatic PPAR $\alpha$ mRNA abundance in our cows was not altered by diet. However, the trend for an interaction among diet, DIM, and bST indicates that prolonged consumption of the diets resulted in greater amounts of PPAR $\alpha$ mRNA in cows fed AF than in those fed SS and that bST administration suppressed this expression in cows 
fed AF, but not in cows fed SS. This interaction of bST and diet on hepatic PPAR $\alpha$ mRNA abundance is consistent with the premise that "cross-talk" occurs between the ST and PPAR $\alpha$ signaling pathways in COS-I cells (Zhou and Waxman, 1999) and rodents (Zhou et al., 2002).

Our study appears to be the first to measure hepatic FGF-21 mRNA in lactating animals. This novel member of the FGF family is preferentially expressed in the liver (Nishimura et al., 2000) and appears to have important endocrine roles in the regulation of lipid and glucose metabolism (Badman et al., 2007; Inagaki et al., 2008). The marked upregulation of FGF-21 mRNA in our cows during early lactation is consistent with reports that hepatic FGF-21 mRNA is increased when animals are in negative energy balance (Badman et al., 2007). Hepatic expression of FGF-21 is induced primarily in a PPAR $\alpha$-dependent manner during fasting (Badman et al., 2007), but PPAR $\alpha$-independent stimulation of FGF-21 has been demonstrated in mice fed a ketogenic diet (Badman et al., 2007). In our cows, the amount of hepatic PPAR $\alpha$ mRNA was unchanged through 24 DIM, while the amount of FGF-21 mRNA increased during early lactation before it returned to prepartum values by 136 DIM. These results indicate possible differences in the FGF-21 signaling mechanism during negative energy balance induced by fasting (Badman et al., 2007; Inagaki et al., 2008) compared with that induced by the onset of lactation (this study). It is also possible that increased PPAR $\alpha$ binding (activation), and not a change in abundance of PPAR $\alpha$ mRNA, influenced FGF-21expression.

Glucose uptake by differentiated 3T3-L1 adipocytes is increased by FGF-21 administration, and this increased uptake occurs primarily through FGF-21-induced expression of GLUT1 (Ogawa et al., 2007). The glucose response to FGF-21 is less robust but more persistent than the glucose response to insulin, which involves the translocation of intracellular GLUT4 to the plasma membrane (Ogawa et al., 2007). This persistent increase in glucose uptake indicates a potential homeorhetic role of FGF-21 in nutrient partitioning. Potential homeorhetic and tissue-specific roles of FGF-21 are supported by the observation that GLUT1 protein and mRNA were greater in mammary than in adipose tissue in early lactation but that the opposite was true as lactation progressed (Komatsu et al., 2005). Inagaki et al. (2008) compared transgenic mice that express FGF-21, administration of FGF-21 to wild-type mice, and fasting of wild-type mice to demonstrate that during fasting, FGF-21 inhibits the signal transducer and activator of transcription 5 signaling pathway downstream of janus kinase 2. Our results support a potential role of FGF21 in uncoupling the ST-IGF-axis during the onset of lactation. The endocrine role of hepatic FGF-21 on fat and glucose metabolism during the periparturient period of the dairy cow warrants further evaluation.

\section{CONCLUSIONS}

This study describes alterations in hepatic expression of genes that have important roles in the coordination of metabolic adaptations during the periparturient period. Results indicate 1) bST-induced increases in hepatic expression of GHR, IGF-I, and IGFBP3 when cows were in negative energy balance in early lactation, 2) no effect of reduced dietary n-6/n-3 content on hepatic gene expression, 3) support for a role of PPAR $\alpha$ in mediation of the interaction of bST and dietary fat on lipid metabolism, and 4) support for a potential homeorhetic role of hepatic FGF-21 in early lactation, possibly through an uncoupling of the ST-IGF-axis.

\section{ACKNOWLEDGMENTS}

Excellent animal care and courteous assistance throughout the study were provided by the staff at the University of Minnesota, Northwest Research and Outreach Center (Crookston, MN). The authors thank Carl Dahlen for his assistance in collection of liver biopsies, Monsanto Co. (St. Louis, MO) for providing recombinant bST, and Alifet USA (Cincinnati, OH) for providing the Alifet-High Energy and Alifet-Repro.

\section{REFERENCES}

Andersen, C. L., J. L. Jensen, and T. F. Orntoft. 2004. Normalization of real-time quantitative reverse transcription-PCR data: A model-based variance estimation approach to identify genes suited for normalization, applied to bladder and colon cancer data sets. Cancer Res. 64:5245-5250.

Badman, M. K., P. Pissios, A. R. Kennedy, G. Koukos, J. S. Flier, and E. Maratos-Flier. 2007. Hepatic fibroblast growth factor 21 is regulated by PPARalpha and is a key mediator of hepatic lipid metabolism in ketotic states. Cell Metab. 5:426-437.

Bauman, D. E. 2000. Regulation of nutrient partitioning during lactation: Homeostasis and homeorhesis revisited. Pages 311-328 in Ruminant Physiology Digestion, Metabolism, Growth and Reproduction. CABI Publishing, New York, NY.

Bell, A. W., and D. E. Bauman. 1997. Adaptations of glucose metabolism during pregnancy and lactation. J. Mammary Gland Biol. Neoplasia 2:265-278.

Berger, J., and D. E. Moller. 2002. The mechanism of action of PPARs. Annu. Rev. Med. 53:409-435.

Bionaz, M., and J. J. Loor. 2007. Identification of reference genes for quantitative real-time PCR in the bovine mammary gland during the lactation cycle. Physiol. Genomics 29:312-319.

Carriquiry, M., W. J. Weber, and B. A. Crooker. 2008. Bovine somatotropin in early lactation: A meta-analysis. J. Dairy Sci. 91:2641-2652.

Carriquiry, M., W. J. Weber, C. R. Dahlen, G. C. Lamb, L. H. Baumgard, and B. A. Crooker. 2009a. Fatty acid composition of milk from multiparous Holstein cows treated with bovine somatotropin and fed n-3 fatty acids in early lactation. J. Dairy Sci. 92:4865-4874.

Carriquiry, M., W. J. Weber, C. R. Dahlen, G. C. Lamb, L. H. Baumgard, and B. A. Crooker. 2009b. Production response of 
multiparous Holstein cows treated with bovine somatotropin and fed diets enriched with n-3 or n-6 fatty acids. J. Dairy Sci. 92:4852-4864.

Carriquiry, M., S. H. Wu, W. J. Weber, H. Chester-Jones, L. B. Hansen, and B. A. Crooker. 2004. Effect of selection for milk yield on hepatic prolactin receptor (PRLR) mRNA in Holstein cows. J. Dairy Sci. 87(Suppl. 1):94. (Abstr.)

Chen, J., D. A. Rider, and R. Ruan. 2006. Identification of valid housekeeping genes and antioxidant enzyme gene expression change in the aging rat liver. J. Gerontol. 61A:20-27.

Clarke, S. D. 2004. The multi-dimensional regulation of gene expression by fatty acids: Polyunsaturated fats as nutrient sensors. Curr. Opin. Lipidol. 15:13-18.

de Kok, J. B., R. W. Roelofs, B. A. Giesendorf, J. L. Pennings, E. T. Waas, T. Feuth, D. W. Swinkels, and P. N. Span. 2005. Normalization of gene expression measurements in tumor tissues: Comparison of 13 endogenous control genes. Lab. Invest. 85:154-159.

Inagaki, T., V. Y. Lin, R. Goetz, M. Mohammadi, D. J. Mangelsdorf, and S. A. Kliewer. 2008. Inhibition of growth hormone signaling by the fasting-induced hormone FGF21. Cell Metab. 8:77-83.

Janovick-Guretzky, N. A., H. M. Dann, D. B. Carlson, M. R. Murphy, J. J. Loor, and J. K. Drackley. 2007a. Housekeeping gene expression in bovine liver is affected by physiological state, feed intake, and dietary treatment. J. Dairy Sci. 90:2246-2252.

Janovick-Guretzky, N. A., H. M. Dann, J. J. Loor, and J. K. Drackley 2007b. Prepartum plane of dietary energy alters hepatic expression of inflammatory and fatty acid oxidation genes in dairy cows. FASEB J. 21:A374. (Abstr.)

Jiang, H., and M. C. Lucy. 2001. Involvement of hepatocyte nuclear factor-4 in the expression of the growth hormone receptor $1 \mathrm{~A}$ messenger ribonucleic acid in bovine liver. Mol. Endocrinol. 15:1023-1034.

Jiang, H., M. C. Lucy, B. A. Crooker, and W. E. Beal. 2005. Expression of growth hormone receptor $1 \mathrm{~A} \mathrm{mRNA}$ is decreased in dairy cows but not in beef cows at parturition. J. Dairy Sci. 88:1370-1377.

Jones, J. I., and D. R. Clemmons. 1995. Insulin-like growth factors and their binding proteins: Biological actions. Endocr. Rev. 16:3-34.

Khan, S. A., and J. P. Vanden Heuvel. 2003. Role of nuclear receptors in the regulation of gene expression by dietary fatty acids. J. Nutr. Biochem. 14:554-567.

Kharitonenkov, A., V. J. Wroblewski, A. Koester, Y. F. Chen, C. K Clutinger, X. T. Tigno, B. C. Hansen, A. B. Shanafelt, and G. J Etgen. 2007. The metabolic state of diabetic monkeys is regulated by fibroblast growth factor-21. Endocrinology 148:774-781.

Komatsu, T., F. Itoh, S. Kushibiki, and K. Hodate. 2005. Changes in gene expression of glucose transporters in lactating and nonlactating cows. J. Anim. Sci. 83:557-564.

Levy, J. R., J. N. Clore, and W. Stevens. 2004. Dietary n-3 polyunsaturated fatty acids decrease hepatic triglycerides in Fischer 344 rats. Hepatology 39:608-616.

Loor, J. J., H. M. Dann, R. E. Everts, R. Oliveira, C. A. Green, N. A. Janovick-Guretzky, S. L. Rodriguez-Zas, H. A. Lewin, and J. K. Drackley. 2005. Temporal gene expression profiling of liver from periparturient dairy cows reveals complex adaptive mechanisms in hepatic function. Physiol. Genomics 23:217-226.

Loor, J. J., H. M. Dann, N. A. Janovick Guretzky, R. E. Everts, R. Oliveira, C. A. Green, N. B. Litherland, S. L. Rodriguez-Zas, H. A. Lewin, and J. K. Drackley. 2006. Plane of nutrition prepartum alters hepatic gene expression and function in dairy cows as assessed by longitudinal transcript and metabolic profiling. Physiol. Genomics $27: 29-41$.

Mashek, D. G., K. L. Ingvartsen, J. B. Andersen, M. Vestergaard, and T. Larsen. 2001. Effects of a four-day hyperinsulinemiceuglycemic clamp in early and mid-lactation dairy cows on plasma concentrations of metabolites, hormones, and binding proteins. Domest. Anim. Endocrinol. 21:169-185.

NRC. 2001. Nutrient Requirements of Dairy Cattle. 7th ed. Natl. Acad. Press, Washington DC.

Nishimura, T., Y. Nakatake, M. Konishi, and N. Itoh. 2000. Identification of a novel FGF, FGF-21, preferentially expressed in the liver. Biochim. Biophys. Acta 1492:203-206.
Odom, D. T., N. Zizlsperger, D. B. Gordon, G. W. Bell, N. J. Rinaldi, H. L. Murray, T. L. Volkert, J. Schreiber, P. A. Rolfe, D. K Gifford, E. Fraenkel, G. I. Bell, and R. A. Young. 2004. Control of pancreas and liver gene expression by HNF transcription factors. Science 303:1378-1381.

Ogawa, Y., H. Kurosu, M. Yamamoto, A. Nandi, K. P. Rosenblatt, R. Goetz, A. V. Eliseenkova, M. Mohammadi, and M. Kuro-o. 2007. $\beta$ Klotho is required for metabolic activity of fibroblast growth factor 21. Proc. Natl. Acad. Sci. USA 104:7432-7437.

Olsson, B., M. Bohlooly-Y, O. Brusehed, O. G. P. Isaksson, B. Ahren, S. Olofsson, J. Oscarsson, and J. Tornell. 2003. Bovine growth hormone-transgenic mice have major alterations in hepatic expression of metabolic genes. Am. J. Physiol. Endocrinol. Metab. 285:E504-E511.

Palin, M. F., and H. V. Petit. 2004. Effects of polyunsaturated fatty acids on hepatic PPAR $\alpha$ mRNA levels in the transition cow. J. Anim. Feed Sci. Polish Acad. Sci. 13(Suppl. 1):445-448.

Radcliff, R. P., B. L. McCormack, B. A. Crooker, and M. C. Lucy. 2003. Growth hormone (GH) binding and expression of $\mathrm{GH}$ receptor $1 \mathrm{~A}$ mRNA in hepatic tissue of periparturient dairy cows. J. Dairy Sci. 86:3933-3940.

Radcliff, R. P., B. L. McCormack, D. H. Keisler, B. A. Crooker, and M. C. Lucy. 2006. Partial feed restriction decreases growth hormone receptor $1 \mathrm{~A}$ mRNA expression in postpartum dairy cows. J. Dairy Sci. 89:611-619.

Rhoads, R. P., J. W. Kim, B. J. Leury, L. H. Baumgard, N. Segoale, S. J. Frank, D. E. Bauman, and Y. R. Boisclair. 2004. Insulin increases the abundance of the growth hormone receptor in liver and adipose tissue of periparturient dairy cows. J. Nutr. 134:1020-1027.

Selberg, K. T., C. R. Staples, N. D. Luchini, and L. Badinga. 2005. Dietary trans-octadecenoic acids upregulate the liver gene enconding peroxisome proliferator activated receptor- $\alpha$ in transition dairy cows. J. Dairy Res. 72:107-114.

Sharma, B. K., M. J. Vandehaar, and N. K. Ames. 1994. Expression of insulin-like growth factor-I in cows at different stages of lactation and in late lactation cows treated with somatotropin. J. Dairy Sci. 77:2232-2241

Sjögren, K., J.-L. Liu, K. Blad, S. Skrtic, O. Vidal, V. Wallenius, D. Le Roith, J. Törnell, O. G. P. Isaksson, J.-O. Jansson, and C. Ohlsson. 1999. Liver-derived insulin-like growth factor I (IGF-I) is the principal source of IGF-I in blood but is not required for postnatal body growth in mice. Proc. Natl. Acad. Sci. USA 96:7088-7092

Vandesompele, J., K. De Preter, F. Pattyn, B. Poppe, N. Van Roy, A. De Paepe, and F. Speleman. 2002. Accurate normalization of realtime quantitative RT-PCR data by geometric averaging of multiple internal control genes. Genome Biol. 3:research0034.1-0034.12.

Wook Kim, J., R. P. Rhoads, S. S. Block, T. R. Overton, S. J. Frank, and Y. R. Boisclair. 2004. Dairy cows experience selective reduction of the hepatic growth hormone receptor during the periparturient period. J. Endocrinol. 181:281-290.

Wu, S. H. 2007. Nutritional physiology of the Holstein selected for milk yield: Effects of energy balance and energy signal variation on the somatotropic axis. PhD thesis. University of Minnesota, St. Paul.

Yamada, J., H. Sugiyama, T. Watanabe, and T. Suga. 1995. Suppressive effect of growth hormone on the expression of peroxisome proliferator activated receptor in cultured rat hepatocytes. Res. Commun. Mol. Pathol. Pharmacol. 90:173-176.

Zhou, Y. C., H. W. Davey, M. J. McLachlan, T. Xie, and D. J. Waxman. 2002. Elevated basal expression of liver peroxisomal $\beta$-oxidation enzymes and CYP4A microsomal fatty acid $\omega$-hydroxylase in STAT5 $\mathrm{b}^{(-/-)}$mice: Cross-talk in vivo between peroxisome proliferator-activated receptor and signal transducer and activator of transcription signaling pathways. Toxicol. Appl. Pharmacol. 182:1-10.

Zhou, Y. C., and D. J. Waxman. 1999. Cross-talk between janus kinase signal transducer and activator of transcription (JAK-STAT) and peroxisome proliferator activated receptor a (PPAR $\alpha)$ signaling pathways. J. Biol. Chem. 274:2672-2691. 